\title{
Total protein composition of young and adult Biomphalaria alexandrina snails with different compatibilities to Schistosoma mansoni infection
}

\author{
Hayam A. Sadaka ${ }^{1}$, Iman F. Abou-El-Naga ${ }^{1 *}$, Eglal I. Amer ${ }^{1}$, Iman H. Diab $^{2}$ \& \\ Safaa I. A. Khedr ${ }^{1}$ \\ 1. Medical Parasitology Department, Faculty of Medicine, Alexandria University, Alexandria, Egypt; \\ hasadaka@hotmail.com, imanabouelnaga@hotmail.com, ehabaman2003@yahoo.com \\ 2. Medical Biochemistry and Molecular Biology Department, Faculty of Medicine, Alexandria University, Alexandria, \\ Egypt; imanhdiab@yahoo.com,siak_1380@yahoo.com \\ * Correspondence
}

Received 04-XI-2015. C Corrected 05-IV-2016. Accepted 06-V-2016.

\begin{abstract}
Schistosomiasis remains a disease of major global public health concern since it is a chronic and debilitating illness. The widely distributed Schistosoma mansoni that causes intestinal schistosomiasis represents a great threat. Its world-wide distribution is permitted by the broad geographic range of the susceptible species of its intermediate host, Biomphalaria, which serves as an obligatory host for the larval stage, at which humans get infected. The objectives were to identify the proteins responsible for the snails' compatibility outcome through differentiation between the total proteins among Biomphalaria alexandrina snails at different ages. The work was conducted on snails that differ in age and genetic backgrounds. Four subgroups (F1) from the progeny of self-reproduced susceptible and resistant snails (F0) were studied. Infection rates of these subgroups (young susceptible, adult susceptible, young resistant and adult resistant) were $90 \%, 75 \%, 40 \%$ and $0 \%$, respectively. Using Sodium Dodecyl Sulphate Polyacrylamide Gel electrophoresis (SDS-PAGE), differences in protein expression were evaluated between adult and young snails of different subgroups. Dice similarity coefficient was calculated to determine the percentage of band sharing among the experimental subgroups. The results showed that the combination of similarities between age and compatibility status of the snails, lead to the highest similarity coefficient, followed by the combination of similarities of both genetic origin and age, even though they differ in the compatibility status. On the other hand, the differences in the genetic background, age and compatibility status, lead to the least similarity index. It was also found that the genetic background in young snails plays a major role in the determination of their compatibility, while the internal defense system has the upper hand in determining the level of adult compatibility. In conclusion, the findings of the present work highlight the great impact of the snail age in concomitance with the genetics and the internal defense in the determination of B. alexandrina/S.mansoni compatibility. Future works are recommended, as further characterization of the shared protein bands among the studied subgroups is needed to clarify their role in host-parasite relationship. Rev. Biol. Trop. 64 (4): 1747-1757. Epub 2016 December 01.
\end{abstract}

Key words: Biomphalaria alexandrina, Schistosoma mansoni, resistant, susceptible, age.

Schistosomiasis remains a disease of major global public health concern and is rated second to malaria in posing chronic and debilitating illness to population. Causing misery and decreasing productivity of the affected organisms, it was nominated as a 'silent pandemic' (Morgan, DeJong, nyder, Mkoji, \& Loker, 2001; Bayne, 2009). It affects more than 249 million people all over the world and is recognized as a major neglected tropical disease (WHO, 2015).

The widely distributed Schistosoma mansoni that causes intestinal schistosomiasis represents a great risk. Its world-wide distribution is permitted by the broad geographic range of the susceptible species of its intermediate host, 
Biomphalaria which serves as an obligatory host for the larval stage, by which humans get infected. Among many identified species of Biomphalaria, Biomphalaria alexandrina is the intermediate host of $S$. mansoni in Egypt (Morgan et al., 2001; Lotfy, DeJong, Black, \& Loker, 2005; Abou-El-Naga, El-Nassery, Allam, Shaat, \& Mady, 2011; Mohamed, ElDin, Mohamed, \& Habib, 2012).

Many control strategies are running for schistosomiasis reduction, however, total elimination of the disease has not yet been achieved. Targeting the parasite's intermediate host snail can certainly break the chain of its life cycle, and hence, decreases schistosomiasis transmission (Steinmann, Keiser, Bos, Tanner, \& Utzinger, 2006).

Molluscs have impressive capacities to protect themselves against infections caused by potential pathogens, which makes the resistance to infection the norm and susceptibility the exception (Bayne, 2009). This assumption explains why Biomphalaria species have different degrees of susceptibility with different internal defense system (IDS) and responses against the invasive $S$. mansoni (Abou-El-Naga, El-Nassery, Allam, \& Mady, 2014). The snails are polymorphic regarding their compatibility with S.mansoni, with susceptible and resistant variants (Coelho et al., 2004). The outcome of the snail/schistosome interaction is governed by the genetic make-up of both the snail and parasite, with successful miracidial development occurring only in susceptible/compatible but not resistant/incompatible snails (Lewis, Patterson, \& Gizywarz, 2002).This considerable degree of intraspecific polymorphism requires investigating variability related factors to susceptibility or resistance in Biomphalaria.

Numerous genetic and physiological factors in both the snail and the parasite are critical for determining Biomphalaria susceptibility to S. mansoni. Snail related factors include their genes, defense system, and age at the time of exposure to miracidia (Richards, Knight, \& Lewis, 1992; Abou- El-Naga \& Radwan, 2012; Abou- El-Naga, Eissa, Mossallam, \& Abd
El-Halim, 2010; Abou-El-Naga, Sadaka, Amer, Diab, \& Khedr, 2015).

Many authors have described the genetic variability related to the interaction between $B$. alexandrina snails and S.mansoni. They were able to determine the polymorphic markers that varied between snails susceptible and resistant to S.mansoni infection (Abdel-Hamid, Rawi, \& Arafa, 2006; El-Nassery, Abou-El-Naga, Allam, Shaat, \& Mady, 2013). The relation between Biomphalaria snails' age and the outcome of infection by S.mansoni has been also studied by many authors. It was found that the resistance of B. glabrata to $S$. mansoni infections appears to be age-dependent and controlled by at least four genes, each with several alleles, while in adulthood, there is only a single dominant gene that determines this trait (Richards \& Shade, 1987; Richards et al., 1992). In B. tenagophila, two dominant genes were found to determine adult resistance (Rosa, Godard, Azevedo, \& Coelho, 2005). Recently, Abou-El-Naga et al. (2015) have focused on the significant impact of $B$. alexandrina age on the snails' compatibility. The authors correlated snails' age, genetic background and internal defense together, and proved that the internal defense of adult snails is more functional, leading to more resistance in adult snails than in young ones. The current work aims to study the impact of age on the total protein composition of $B$. alexandrina snails with different genetic backgrounds, using the electrophoretic separation approach.

\section{MATERIALS AND METHODS}

Snails and parasites; collection and maintenance: $S$. mansoni strain was originally harvested from shedding cercariae obtained from naturally infected $B$. alexandrina snails collected from Abis village drainage ditch, Alexandria, Egypt in the year 2011. Since then, all snails were maintained in aquaria containing dechlorinated tap water (DTW) at a temperature of $25^{\circ} \mathrm{C}$, and at darkness for the exposed snails to prevent cercarial shedding. Snails were fed fresh green lettuce leaves, supplemented 
with fish food and calcium carbonate. Water change and food application were repeated twice weekly. Maintenance of $S$. mansoni life cycles was conducted between our laboratory snails and Swiss strain albino mice (Abou- ElNaga et al., 2010). All animal studies were conducted at the animal experimentation facility of the Medical Parasitology Department, Faculty of Medicine, Alexandria University, Egypt. This was done with strict accordance to institutional ethical guidelines for the use of animals in research and the study protocol was approved by the Ethics Committee of Faculty of Medicine, Alexandria University, Egypt (Protocol approval number 020403).

Selection of the susceptible and resistant snail stocks: Separation of resistant and susceptible isolates (F0) was achieved according to Zanotti-Magalhães, Magalhães and Carcalho (1997) and El-Nassery et al. (2013). For selection of resistant isolates, snails that remained un-infected after two parasitic exposures, each by ten active freshly hatched miracidia/snail, were isolated and reared singly for self-reproduction under laboratory conditions (Eveland \& Haseeb, 2011). Their progeny (F1) were selected to be the experimental resistant group. For selecting susceptible isolate, progeny of snails that yielded high infection frequencies, were isolated and reared singly for self-reproduction.

Rearing and infection of the experimental snails: From the progeny of the susceptible and resistant groups, 100 young susceptible (subgroup Ia) and 100 young resistant (subgroup II a) snails were infected by individual exposure to 8-10 vigorously swimming freshly hatched miracidia in palettes, each palette was with six wells, each well accommodated one snail with $2 \mathrm{~mL}$ of de-chlorinated tap water. Palettes were directly exposed to sunlight for 3-4 hours (Eveland \& Haseeb, 2011), until snail reached the age of two months and the size of 3-4 millimeters in diameter. Additionally, 100 adult susceptible (subgroup I b) and 100 adult resistant (subgroup II b) snails were infected at the age of four months, and the size of 8-10 millimeters in diameter. Posterior to the exposure of the 400 snails to miracidia (each snail with 8-10 miracidia), infected snails of each of the subgroups Ia, Ib, IIa, and IIb were placed in separate plastic aquaria; one for each subgroup. Exposed snails of all subgroups were kept in darkness for about four weeks to prevent cercarial shedding (Eveland \& Haseeb, 2011). Later, snails were used for the determination of the parasitological parameter, as well as for the electrophoretic study (Abou-El-Naga et al., 2010).

Determination of susceptibility and resistance of snails: Four weeks post infection exposure; snails of all subgroups were individually checked for cercarial shedding twice a week, for three successive weeks. Susceptible and non-shedding snails of each subgroup were separated and placed in different aquaria. Non-shedding individuals for each subgroup were tested twice weekly for cercarial shedding until the $49^{\text {th }}$ day post infection (first infection). By the end of the three weeks, non-shedding snails were examined under the dissecting microscope, to assure that there are no any arrested developmental stages (Niemann \& Lewis, 1990), and the percentage of susceptible and resistant snails in each subgroup was determined.

Electrophoretic study: Seven weeks post infection, the same snails were used for SDSPAGE (El-Dafrawy, El-Din, \& Hamid, 2006), with 10 uninfected young and 10 uninfected adult snails. Each snail was cleaned well by gentle scrubbing using a soft tooth brush and distilled water. Soft tissue of the dissected snail was obtained and perused with saline solution; it was weighed and homogenized with $1 \mathrm{~mL}$ of phosphate-buffer saline by sonic circulation for two minutes in a test tube embedded in ice. The homogenized tissue was centrifuged at $500 \mathrm{xg}$ for 4 minutes and the supernatant containing the proteins was stored at $-20^{\circ} \mathrm{C}$ until used for SDS-PAGE study (El-Dafrawy et al., 2006). Molecular weights of separated proteins 
were measured with the aid of a protein marker (wide range molecular weight standard mixture (212-6.5 Kilo Daltons, Kda; Standard protein marker was purchased from Bio Basic Inc, Canada). Subsequently, gels were photographed and analyzed by Totallab Analysis Software Program 2013 (http://totallab.com/). The percentage band sharing was calculated by Dice similarity coefficient (Dice, 1945).

Data were analyzed using IBM SPSS software package version 20.0. (Kirkpatrick \& Feeney, 2013).

\section{RESULTS}

Infection rate: In this work, 90 snails of young susceptible subgroup (Ia) were susceptible and 10 snails were resistant; 40 snails belonging to young resistant subgroup (IIa) shed cercariae, while 60 snails did not. Furthermore, 75 individuals released cercariae in the adult susceptible subgroup (Ib) while 25 did not; whereas the adult resistant subgroup (IIb) contained only resistant members. The infection rates of the subgroups young susceptible, adult susceptible, young resistant and adult resistant were $90 \%, 75 \%, 40 \%$ and $0 \%$, respectively.

Electrophoretic study: The results of the electrophoretic study are shown in table 1 and table 2 and figure 1, while table 3 shows the Dice similarity coefficient. The SDS-PAGE results revealed that young snails' tissue proteins exhibited a complex pattern of polypeptides with a total number of nine, nine, nine, ten and 11 bands, in young non infected, subgroup Ia (susceptible members, resistant members), subgroup IIa (susceptible members and resistant members), respectively. Protein molecular weights ranged from 196.739 to 2.930 (Table 1). On the other hand, the number of bands in adult snail subgroups was 13, 16, 16 and 17 bands in adult non infected, subgroup Ib (susceptible members and resistant members) and subgroup IIb, respectively. Their molecular weights ranged from 204.353 to $2.930 \mathrm{KDa}$ (Table 2). The differences between young and adult non-infected snails were the number of protein bands detected since we found 9 non-infected young, and 13 in non-infected adults. The similarity index between the two non-infected groups was calculated to be 0.75 as shown in table 3.

Furthermore, a new finding is the difference between adult and young snails possessing the same genetic origin and compatibility pattern, for which differences were noted between susceptible members of subgroups Ia and Ib, resistant members of subgroups $\mathrm{Ia}$ and $\mathrm{Ib}$, and resistant members of subgroups IIa and IIb, being, 0.6, 0.64 and 0.62 , respectively, as shown in Table 3.

Regarding adult subgroups, many shared proteins were observed (Table 2). A band of MW 55.597 KDa was obtained in the four lanes corresponding to the adult subgroups and their control. The bands of MW 16.738 and 14.846 KDa were shared by the three lanes corresponding to the samples of exposed adult subgroups.

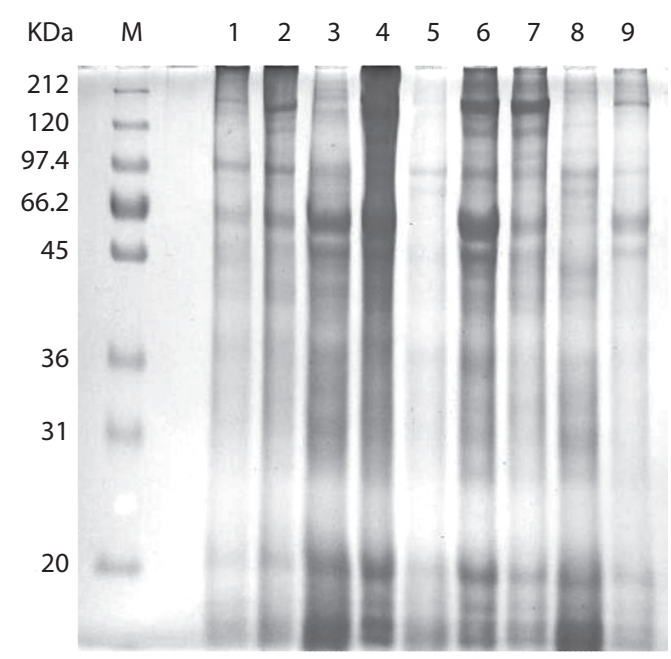

Fig. 1. Peptide mapping of Biomphalaria alexandrina snails' tissue of the studied subgroups using SDSPAGE. M:Protein marker; 1: Non-infected young snails; 2: subgroup Ia (susceptible members); 3: subgroup Ib (susceptible members); 4: subgroup IIa (resistant members); 5: subgroup IIa (susceptible members); 6: subgroup Ib (resistant members); 7: Non-infected adult); 8: subgroup IIb (adult resistant); 9: subgroup Ia (resistant members). The figure shows number of peptide bands, their intensity and their molecular weights. 
TABLE 1

SDS-PAGE analysis, showing number of peptide bands and molecular weights of the studied uninfected young group and infected young subgroups

\begin{tabular}{|c|c|c|c|c|c|c|}
\hline \multirow[b]{2}{*}{ Fraction } & \multicolumn{6}{|c|}{ Molecular Weight (Kilo Dalton) } \\
\hline & $\begin{array}{l}\text { Protein } \\
\text { marker }\end{array}$ & $\begin{array}{c}\text { (Non-infected young) } \\
\text { Lane } 1\end{array}$ & $\begin{array}{c}\text { Subgroup Ia } \\
\text { (susceptible members) } \\
\text { Lane } 2\end{array}$ & $\begin{array}{c}\text { Subgroup Ia } \\
\text { (resistant members) } \\
\text { Lane } 9\end{array}$ & $\begin{array}{c}\text { Subgroup IIa } \\
\text { (susceptible members) } \\
\text { Lane } 5\end{array}$ & $\begin{array}{c}\text { Subgroup IIa } \\
\text { (resistant members) } \\
\text { Lane } 4\end{array}$ \\
\hline 1 & 212.000 & & & & & \\
\hline 2 & & & & 196.739 & & \\
\hline 3 & & & & & 174.426 & 174.426 \\
\hline 4 & & & & & 124.635 & 124.635 \\
\hline 5 & 120.000 & & & & & \\
\hline 6 & & 115.819 & 115.819 & 115.819 & & \\
\hline 7 & 97.400 & & & & & \\
\hline 8 & & 93.600 & 93.600 & 93.600 & 93.600 & 93.600 \\
\hline 9 & & 67.596 & & & 69.002 & \\
\hline 10 & 66.200 & & & & & 63.452 \\
\hline 11 & & & 59.448 & 59.448 & & \\
\hline 12 & & & & & 44.009 & 44.009 \\
\hline 13 & & & & & & 34.680 \\
\hline 14 & 31.000 & 30.349 & & & & \\
\hline 15 & & & 26.100 & 27.014 & & \\
\hline 16 & 20.000 & 20.758 & 20.380 & 20.380 & 20.124 & 20.124 \\
\hline 17 & & & 18.655 & & & \\
\hline 18 & & & & & & \\
\hline 19 & & 17.471 & 16.873 & 16.873 & 16.547 & 16.547 \\
\hline 20 & 15.000 & 15.099 & & & 15.062 & 15.161 \\
\hline 21 & 14.400 & & & & & \\
\hline 22 & 6.500 & 7.297 & 7.297 & 6.999 & 6.999 & 6.999 \\
\hline 23 & 2.972 & 2.930 & 3.158 & 3.158 & 3.128 & 3.128 \\
\hline Number of & oands & 9 & 9 & 9 & 10 & 11 \\
\hline
\end{tabular}

Ia: young susceptible subgroup.

IIa: young resistant subgroup.

The highest similarity index recorded was between adult resistant subgroup and resistant members of adult susceptible subgroup, being 0.89 , with seven shared bands between them; these had MW of 196.739, 82.839, 28.565, $14.169,12.991,6.424$ and $4.373 \mathrm{Kda}$, respectively. On the other hand, only one band was shared by adult susceptible subgroup members of different compatibility status being 20.380 .

As for young subgroups, five common bands were shared between susceptible and resistant members of young susceptible subgroup of MW of 115.819, 59.448, 20.380, 16.873 and $3.158 \mathrm{KDa}$. Additionally, 6 common bands were shared between susceptible and resistant members of young resistant subgroup of MW of 174.426, 124.635, 44.009, 20.124, 16.547 and $3.128 \mathrm{KDa}$ (Table 1). Coefficients of 0.85 and 0.84 , were recorded between subgroup Ia resistant $\&$ susceptible members and subgroup IIa resistant \& susceptible members respectively (Table 3 ).

\section{DISCUSSION}

The genetic background of $B$. alexandrina snails greatly affects their compatibility status to $S$. mansoni infection (Abou- El-Naga et al., 
TABLE 2

SDS-PAGE analysis, showing number of peptide bands and molecular weights of the studied non-infected adult group and infected adult subgroups

\begin{tabular}{|c|c|c|c|c|c|}
\hline \multirow[b]{2}{*}{ Fraction } & \multicolumn{5}{|c|}{ Molecular weight (kilo Dalton) } \\
\hline & Protein marker & $\begin{array}{c}\text { (Non-infected adult) } \\
\text { Lane } 7\end{array}$ & $\begin{array}{c}\text { Subgroup Ib } \\
\text { (Susceptible members) } \\
\text { Lane } 3\end{array}$ & $\begin{array}{c}\text { Subgroup Ib } \\
\text { (Resistant members) } \\
\text { Lane } 6\end{array}$ & $\begin{array}{c}\text { Subgroup Ilb } \\
\text { (Adult resistant) } \\
\text { Lane } 8\end{array}$ \\
\hline 1 & 212.000 & & & & \\
\hline 2 & & 204.353 & & 196.739 & 196.739 \\
\hline 3 & & & 140.989 & & \\
\hline 4 & & & & & 129.700 \\
\hline 5 & & & & 124.635 & \\
\hline 6 & 120.000 & 120.000 & & & \\
\hline 7 & & & 103.290 & & \\
\hline 8 & 97.400 & & & & 94.111 \\
\hline 9 & & 93.600 & 93.600 & 93.600 & 93.600 \\
\hline \multicolumn{6}{|l|}{10} \\
\hline 11 & & & & 82.839 & 82.839 \\
\hline 12 & & 74.663 & & & \\
\hline 13 & 66.200 & 64.818 & 64.818 & & \\
\hline 15 & & 55.597 & 55.597 & 55.597 & 55.597 \\
\hline 16 & & 45.073 & 44.009 & & \\
\hline 17 & & & & & 39.962 \\
\hline 18 & 31.000 & & & & \\
\hline 19 & & & & 28.565 & 28.565 \\
\hline 20 & & 24.189 & 24.189 & & \\
\hline 21 & 20.000 & 19.523 & 20.380 & 20.380 & \\
\hline 22 & & & & 18.554 & 18.861 \\
\hline 23 & & 17. 391 & 17.391 & & \\
\hline 24 & & & 16.738 & 16.738 & 16.738 \\
\hline 25 & 15.000 & & 15.119 & & \\
\hline 26 & & & & 14.962 & 14.951 \\
\hline 27 & & & 14.846 & 14. 846 & 14. 846 \\
\hline 28 & 14.400 & & 14.652 & & \\
\hline 29 & & & & 14.169 & 14. 169 \\
\hline 30 & & & 13.920 & & \\
\hline 32 & & & & 12.991 & 12.991 \\
\hline 33 & 6.500 & 6.424 & 6.799 & 6.424 & 6.424 \\
\hline 34 & & 4.145 & & 4.373 & 4.373 \\
\hline 35 & & & & & 3.006 \\
\hline 36 & 2.972 & 2.930 & 2.930 & 2.930 & \\
\hline Number o & f bands & 13 & 16 & 16 & 17 \\
\hline
\end{tabular}

Ib: adult susceptible subgroup.

IIb: adult resistant subgroup. 


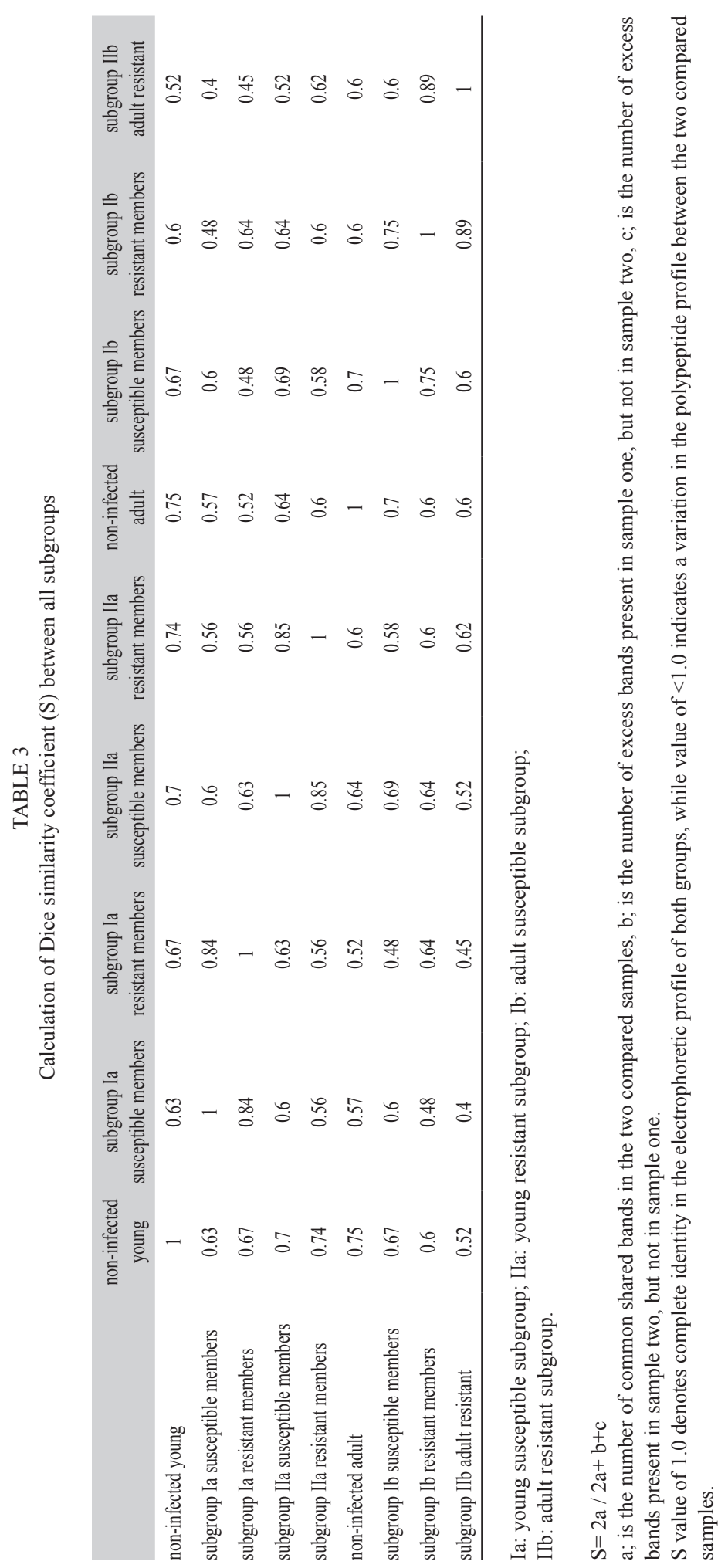


2015). Differentiation of total proteins among these snails at dissimilar ages could be of great benefit to identify the proteins responsible for the snails' compatibility outcome.

Although our experiment was carried out on snails resulting from self-fertilization, resistant snails were obtained in the progeny of susceptible members. This finding indicates dominance of the resistant character in B. alexandrina. Despite resistance alleles being often hidden from the snail phenotype, they group together through generations, causing resistant phenotype to appear. Their parents carried unexpressed resistance genes, and the resistance alleles grouped among successive generations (Abou- El- Naga et al., 2010; 2015). Similarly, resistance character in $B$. glabrata and $B$. tenagophila snails is inherited in a dominant way (Richards \& Merritt, 1972; Lewis et al., 2002; Rosa et al., 2005). Abdel-Hamid et al., (2006) and El-Nassery et al., (2013) found that both susceptibility and resistance in $B$. alexandrina are hereditary characters which are genetically controlled.

Whilst the two susceptible subgroups, in the current work, contained resistant members, the notable distinction between them indicates that the resistant alleles obtained from $F_{1}$ parents were potentiated by the impact of age resulting in the appearance of more resistant members in the adult susceptible subgroup (Ib).

Moreover, the recorded differences of the complex polypeptides pattern between young and adult non-infected snails, and the calculated similarity index between them, indicates changes in the protein content in the snail tissue with age. This may be responsible for egg laying capacity, or can be attributed to other physiological changes with the aging process itself.

Regarding adult subgroups, the shared protein band of MW 55.597 KDa among the four lanes corresponding to the adult subgroups and their control, may be the protein that is present only in adult $B$. alexandrina whether infected or not. On the other hand, the shared bands of MW 16.738 and $14.846 \mathrm{KDa}$ by the three lanes corresponding to the exposed adult subgroups, may represent proteins that appear in adult $B$. alexandrina corresponding to adult snail defense against $S$. mansoni. Additionally, the shared proteins between adult subgroups, susceptible or resistant, could be responsible for the lower compatibility met in adult susceptible snails. Interestingly, the highest similarity index of 0.89 was observed-between adult resistant subgroup and resistant members of adult susceptible subgroup, while the lowest one of 20.380 was recorded by the adult susceptible subgroup members of different compatibility status. Therefore, it is evident that internal defense in adult $B$. alexandrina is more important than its genetic origin, as shared bands between snails of the same compatibility pattern and different genetic origins were more in number than those shared between snails of the same genetic origin and different compatibility patterns.

In contrast to adult subgroups, where internal defense has the upper hand, a disparate scenario was present in young subgroups, at which many shared proteins were observed between snails possessing the same genetic origin regardless of their compatibility patterns. This can be attributed to the similarities of both genetic origin and age, although there were differences in compatibility for snails in both cases. Thus, it can be assumed that genetic origin in young $B$. alexandrina is more important than its internal defense, causing many shared bands to appear between snails of the same genetic origin and different compatibility patterns.

Indispensable to mention is that despite that many shared bands possessing the same molecular weights were observed between subgroups belonging to the same age, each shared protein band may represent more than one protein that require further molecular analysis.

Interestingly, a common shared band of MW 93.600 KDa was noticed in all the lanes. This indicates that this protein is of B. alexandrina snail, which is neither influenced by the snail's age, the genetic origin nor by schistosome infection.

The effect of schistosome infection on the protein content within the snails can be observed 

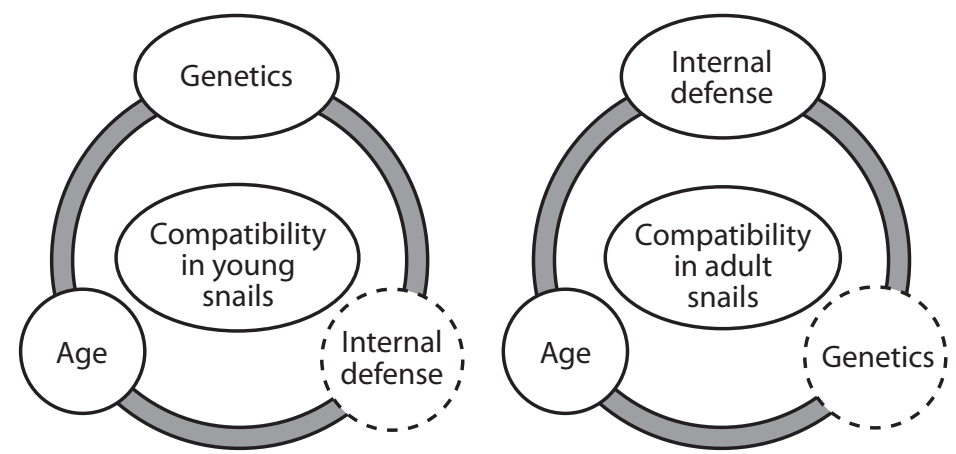

Fig. 2. The effect of complex interaction between age, genetic background and internal defense on determination of compatibility status in young and adult Biomphalaria alexandrina snails. Genetic background has the upper hand in young snails while internal defense has the upper hand in adult snails.

between infected and non-infected peers of the same age. Indices of 0.63 and 0.7 were recorded between non-infected young with subgroup Ia susceptible members and subgroup IIa susceptible members, respectively. Index of 0.7 was recorded between non-infected adult and subgroup Ib susceptible members. The effect of infection led to appearance and disappearance of several protein bands in infected compared to control, where the development of intra-molluscan larval stages of the parasite within the parasitized snails has altered the electrophoretic profile of its tissue proteins. This alteration in protein fractionation can be attributed to the presence of parasite proteins and also to the presence of some degree of immune response, whether cellular or humoral that is exhibited by the snails against the invading parasite, indicating the production of new proteins in response to infection (Raghavan et al., 2003). Using the same technique, many researchers reported that tissue proteins of $S$. mansoni $-B$. alexandrina complex, have a different protein pattern when compared to non-infected snails. They revealed that this complex had a low similarity coefficient with the non-infected (Mohamed, 2005; El-Dafrawy et al., 2006).

The calculated similarity indices between the non-infected groups and the resistant members of the subgroups belonging to the same age were 0.67 and 0.74 between non-infected young and resistant members of subgroups Ia and Iia, respectively. Additionally, indices of 0.6 and 0.6 were calculated between non-infected adult and resistant members of subgroups Ib and Iib, respectively. The differences can be accredited to the activation of cellular and humoral elements of the snail's immune response against the invading parasite (Raghavan et al., 2003). Accordingly, the highest similarity coefficient was found between subgroup IIb adult resistant \& subgroup Ib resistant members, being 0.89 , which can be allocated to the combination of similarities between both age and compatibility status. Moreover, coefficients of 0.85 and 0.84 were calculated between subgroup Ia resistant and susceptible members, and subgroup IIa resistant and susceptible members, respectively. This can be ascribed to the similarities of both genetic origin and age, even though there were differences in compatibility for snails in both cases. On the contrary, the least similarity index was observed between the most resistant subgroup in our experiment (IIb adult resistant) and the most susceptible subgroup (Ia susceptible members) being 0.4 , where the differences between the two subgroups were related to genetic, age and compatibility status. Further verification of the protein profile of $B$. alexandrina snails of different compatibilities at varying ages, using more advanced approaches is currently on under way. We concluded that the results of the present work spotted the light on the substantial role of the snail age in concomitance with the genetics and the internal defense in determination of $B$. alexandrina/S.mansoni compatibility as shown in figure 2 . 


\section{ACKNOWLEDGMENTS}

Laboratories and equipment that were used for this research belong to Medical Parasitology Department, Faculty of Medicine, Alexandria University, Egypt.

\section{RESUMEN}

Composición total de proteína en caracoles Biomphalaria alexandrina juveniles y adultos con distintas compatibilidades a la infección por Schistosoma mansoni. La esquistosomiasis es una enfermedad crónica y debilitante que constituye una problemática de salud pública a nivel mundial. Debido a que Schistosoma mansoni está ampliamente distribuida y a que es el causante de la esquistosomiasis intestinal representa una gran amenaza. Biomphalaria es el hospedero intermedio y obligatorio para el estado larval, presenta una amplia distribución geográfica e infecta al ser humano. El objetivo fue identificar las proteínas responsables del efecto de compatibilidad en caracoles Biomphalaria alexandrina de distintos estadios a través de la diferenciación del total de proteínas en ellos. La investigación se llevó a cabo con caracoles de diferentes edades y antecedentes genéticos. Se estudiaron cuatro subgrupos (F1) de la progenie de caracoles susceptibles y resistentes reproducidos asexualmente (F0). Las tasas de infección de estos subgrupos (juvenil susceptible, adulto susceptible, juvenil resistente, adulto resistente) fueron 90 $\%, 75 \%, 40 \%$ y $0 \%$, respectivamente. Con la electroforesis en gel de poliacrilamida en presencia de dodecilsulfato sódico (SDS-PAGE) se evaluaron las diferencias en la expresión proteica entre los caracoles juveniles y adultos de los distintos subgrupos. Se calculó el coeficiente de similitud de Dice para determinar el porcentaje de bandas compartidas entre los subgrupos experimentales. Los resultados mostraron que la combinación de similitudes entre la edad y el estado de compatibilidad de los caracoles genera el mayor coeficiente de similitud seguido por el de la combinación de similitudes tanto de la edad como del origen genético aunque varían en el estado de compatibilidad. Por otra parte, las diferencias en los antecedentes genéticos, la edad y el estado de compatibilidad generan el índice de similitud más bajo. También se encontró que el antecedente genético en caracoles juveniles es importante en la determinación de su compatibilidad, mientras que el sistema de defensa interno es el que determina el nivel de compatibilidad en adultos. En conclusión, los resultados de este trabajo resaltan la importancia de la edad del caracol en conjunto con la genética y la defensa interna para determinar la compatibilidad de B. alexandrina/S.mansoni. Se recomienda realizar futuros trabajos así como una mayor caracterización de las bandas proteicas compartidas entre los subgrupos estudiados para esclarecer su papel en la relación hospedero-parásito.
Key words: Biomphalaria alexandrina, Schistosoma mansoni, resistencia, susceptibilidad, edad.

\section{REFERENCES}

Abdel-Hamid, Z. A., Rawi, S. M., \& Arafa, A. F. (2006). Identification of genetic marker associated with the resistance to Schistosoma mansoni infection using random amplified polymorphic DNA analysis. Memórias do Instituto Oswaldo Cruz, 101, 863-868.

Abou-El-Naga, I. F., Eissa, M. M., Mossallam, S. F., \& Abd El-Halim, S. I. (2010). Inheritance of Schistosoma mansoni infection incompatibility in Biomphalaria alexandrina snails. Memórias do Instituto Oswaldo Cruz, 105, 149-154.

Abou-El-Naga, I. F., El-Nassery, S. M. F., Allam, S. R., \& Mady, R. F. M. (2014). In vitro interactions between the defense systems of resistant and susceptible Biomphalaria alexandrina and sporocysts of Schistosoma mansoni. Veterinary Parasitology, 205, 712-716.

Abou-El-Naga, I. F., El-Nassery, S. M., Allam, S. R., Shaat, E. A., \& Mady, R. F. (2011). Biomphalaria species in Alexandria water channels. Parasitology International, 60(3), 247-254.

Abou-El-Naga, I. F., \& Radwan, E. H. (2012). Defense response of susceptible and resistant Biomphalaria alexandrina snails against Schistosoma mansoni infection. Revista de Biología Tropical, 60(3), 1195-1204.

Abou-El-Naga, I. F., Sadaka, H. A., Amer, E. I., Diab, I. H., \& Khedr, S. I. A. (2015). Impact of Biomphalaria alexandrina snails' age on transmission of Schistosoma mansoni: Modulation of the genetic outcome and the internal defense system of the snail. Memórias do Instituto Oswaldo Cruz, 110(5), 585-595.

Bayne, C. J. (2009). Successful parasitism of vector snail Biomphalaria glabrata by the human blood fluke (trematode) Schistosoma mansoni: a 2009 assessment. Molecular and Biochemical Parasitology, 165(1), 8-18.

Coelho, P. M., Carvalho, O. S., Andrade, Z. A., MartinsSousa, R. L., Rosa, F. M., \& Barbosa. L. (2004). Biomphalaria tenagophila/Schistosoma mansoni interaction: premises for a new approach to biological control of schistosomiasis. Memórias do Instituto Oswaldo Cruz, 99(1), 109-111.

Dice, L. R. (1945). Measures of the amount of ecological association between species. Ecology, 26, 297-302.

El-Dafrawy, S. M., El-Din, A. T., \& Hamid, H. A. (2006). Electrophoretic patterns of protein fractionations in hemolymph and tissues of Biomphalaria alexandrina and Bulinus truncatus during course of schistosome 
infection. Journal of the Egyptian Society of Parasitology, 36(3), 795-807.

El-Nassery, S. M., Abou-El-Naga, I. F., Allam, S. R., Shaat, E. A., \& Mady, R. F. (2013). Genetic variation between Biomphalaria alexandrina snails susceptible and resistant to Schistosoma mansoni infection. Biomed Reearchs Inernational, 160320.doi: $10.1155 / 2013 / 160320$.

Eveland, L. K., \& Haseeb, M. A. (2011). Laboratory Rearing of Biomphalaria glabrata Snails and Maintenance of Larval Schistosomes In Vivo and In Vitro. In Biomphalaria Snails and Larval Trematodes (pp. 33-55). New York: Springer.

Kirkpatrick, L. A., \& Feeney, B. C. (2013). A simple guide to IBM SPSS statistics for version 20.0. Student ed. Belmont, Calif.: Wadsworth, Cengage Learning.

Lewis, F. A., Patterson, C. N., \& Gizywarz, C. (2002). Parasite susceptibility phenotypes of F1 Biomphalaria glabrata progeny derived from interbreeding of Schistosoma mansoni resistant and susceptible snails. Parasitology Research, 89, 98-101.

Lotfy, W. M., DeJong, R. J., Black, B. S., \& Loker, E. S. (2005). Specific identification of Egyptian Biomphalaria species and possible hybrids using the polymerase chain reaction based on nuclear and mitochondrial loci. Molecular and Cellular Probes, 19(1), 21-25.

Mohamed, A. H. (2005). Characterization of surface lectins binding and SDS-PAGE protein patterns of Biomphalaria alexandrina haemocytes infected with Schistosoma mansoni. Journal of the Egyptian Society of Parasitology, 35(2), 615-630.

Mohamed, A. H., El-Din, A. T., Mohamed, A. M., \& Habib, M. R. (2012). The relationship between genetic variability and the susceptibility of Biomphalaria alexandrina snails to Schistosoma mansoni infection. Memórias do Instituto Oswaldo Cruz, 107(3), 326-337.

Morgan, J. A., DeJong, R. J., Snyder, S. D., Mkoji, G. M., \& Loker, E. S. (2001). Schistosoma mansoni and Biomphalaria: past history and future trends. Parasitology, 123(1), 211-228.
Niemann, G. M., \& Lewis, F. A. (1990). Schistosoma mansoni: influence of Biomphalaria glabrata size on susceptibility to infection and resultant cercarial production. Experimental Parasitology, 70, 286-292.

Raghavan, N., Miller, A. N., Gardner, M., Fitz-Gerald, P. C., Kerlavage, A. R., Johnston, D. A., \& Knight, M. (2003). Comparative gene analysis of Biomphalaria glabrata hemocytes pre- and post-exposure to miracidia of Schistosoma mansoni. Molecular and Biochemical Parasitology, 126(2), 181-91.

Richards, C. S., Knight, M., \& Lewis, F. A. (1992). Genetic of Biomphalaria glabrata and its effect on the outcome of Schistosoma mansoni infection. Parasitology Today, 8(5), 171-174.

Richards, C. S., \& Merritt, J. R. (1972). Genetic factors in the susceptibility of juvenile Biomphalaria glabrata to Schistosoma mansoni infection. The American Journal of Tropical Medicine and Hygiene, $21,425-434$.

Richards, C. S., \& Shade, P. C. (1987). The genetic variation of compatibility in Biomphalaria glabrata and Schistosoma mansoni. Journal of Parasitology, 73(6), 1146-1151.

Rosa, F. M., Godard, A. L. B., Azevedo, V., \& Coelho, P. M. Z. (2005). Biomphalaria tenagophila: dominant character of the resistance to Schistosoma mansoni in descendants of cross breedings between resistant (Taim, RS) and susceptible (Joinville, SC) strains. Memórias do Instituto Oswaldo Cruz, 100(1), 19-23.

Steinmann, P., Keiser, J., Bos, R., Tanner, M., \& Utzinger, J. (2006). Schistosomiasis and water resources development: systematic review, meta-analysis, and estimates of people at risk. The Lancet of Infectious Diseases, 6(7), 411-425.

W.H.O. (2015). Schistosomiasis Fact Sheet. No.115. (Updated 2015) http://www.who.int/mediacentre/ factsheets/fs $115 / \mathrm{en} /$.

Zanotti-Magalhães, E. M., Magalhães, L. A., \& Carcalho, J. F. (1997). Relationship between pathogenicity of Schistosoma mansoni in mice and the susceptibility of the vector mollusk. IV-Infectiousness of miracidia. Revista de Saúde Pública, 31(5), 488-494. 
